\title{
TINJAUAN HUKUM ISLAM TERHADAP ISTRI SEBAGAI PENCARI NAFKAH
}

(Studi Kasus Masyarakat Desa Pambusuang Kec. Balanipa Kab. Polewali Mandar)

\section{Rahmah Mu'in}

Prodi Hukum Ekonomi Syariah, Fakultas Agama Islam, Universitas Al Asyariah Mandar rahmah_muin@gmail.com

\begin{abstract}
Abstrak
Penelitian ini bertujuan untuk: (1) Mengetahui bagaimana potret istri di Desa Pambusuang dalam mencari nafkah. (2) Mengetahui pandangan Hukum Islam terhadap istri yang membantu mencukupi kebutuhan ekonomi keluarga. Penelitian ini menggunakan metode pendekatan kualitatif. Objek penelitian adalah Tinjauan Hukum Islam dan Keikutsertaan Istri dalam pemberian nafkah rumah tangga. Data yang terkumpul kemudian dianalisis dengan metode analisis-deskriptif. Hasil penelitian ini menunjukkan bahwa Kepemimpinan laki-laki dalam rumah tangganya adalah sebuah keistimewaan, tetapi sekaligus tanggung jawab yang tidak kecil. Hal yang tidak kecil ini termasuk mencari nafkah untuk keluarga. Namun, dewasa ini banyak istri yang ikut serta menafkahi rumah tangganya dan hal ini merupakan kerjasama antar suami istri yang ternyata tetap diperbolehkan dengan berbagai syarat yang mengikatnya. Walaupun kewajiban mencari nafkah untuk anak dan istri dibebankan kepada suami, tetapi istri hendaknya dapat membantu memenuhi kebutuhan tersebut, bahkan bila perlu ikut bekerja mancari nafkah. Catatatn penting yang perlu dihayati oleh pasangan suami istri, yaitu betapa besar penghasilan isteri jika melebihi penghasilan suami, tidak berarti jika isteri berhak mendekte suami sesuai kehendaknya, dan keadaan tersebut tidak boleh membuat suami rendah diri. Dan dalam keadaan yang sama suami tidak berhak memaksa isteri untuk membelanjakan penghasilannya untuk kebutuhan rumah tangga. Pasalnya, sejak zaman Rasulullah terdapat banyak lini pekerjaan yang dipegang oleh perempuan. Syarat fundamental terpenting adalah Ridla dari suami. Dan istri tetap bisa memiliki akses ekonomi untuk dirinya. Harta yang dimiliki adalah hartanya dan tidak bisa dimiliki orang lain. Istri yang ikut menafkahi keluarganya secara ikhlas bisa mendapatkan pahala ganda dari bersadaqah dan bekerja. Dan bagi suami, istri yang memiliki pekerjaan meski bisa mencukupi nafkah dirinya sendiri namun, suami tetap berkewajiban memenuhi nafkah istrinya. Kecuali memang tersendat perekonomiannya. Dan sebaliknya istri yang menafkahi suaminya maka nafkah tersebut bisa dihitung sebagai hutang suami terhadap istri dan wajib diganti saat suami sudah memiliki uang, kecuali jika istri sudah benar-benar ridla dengan harta tersebut. Karena sesungguhnya dalam rumah tanggapun diajari untuk saling tolong menolong.(Kata Kunci: Istri, Nafkah, Rumah Tangga, Hukum Islam).
\end{abstract}

Kata Kunci: Hukum Islam, Istri, Pencari Nafkah

\section{PENDAHULUAN}

Dalam kehidupan yang dijalani terlihat jelas adanya berbagai pasangan: senangsusah, siang-malam, pagi-sore, siang-malam, dan lain sebagainya. Bentuk pasangan tersebut merupakan ketetapan yang diatur oleh Allah SWT, bukan hanya pada manusia saja, akan tetapi untuk seluruh makhluk-Nya. Manusia berpasangan akan melahirkan sebuah bentuk 
kerjasama, dengan adanya kerjasama maka hidup akan menjadi harmonis. Pernikahan bukanlah hanya untuk kemaslahatan dunia saja akan tetapi juga diniatkan untuk meraih kebahagian akhirat, keluarga biasanya terdiri dari bapak, ibu, dan anak-anak atau orang seisi rumah yang menjadi tanggungannya. Pasal 34 ayat 1 UU No. 1 Tahun 1974 tentang perkawinan, menjelaskan bahwa seorang suami wajib melindungi istrinya dan memberikan segala sesuatu keperluan hidup rumah tangga sesuai dengan kemampuannya. Pasal 34 ayat 2 UU No. 1 tahun 1974, menjelaskan bahwa istri wajib mengatur urusan rumah tangga sebaikbainya. Syari'at Islam tidak berhenti pada pembatasan hak dan kewajiban timbal balik antar keduanya hingga hidup secara komitmen tanpa memperdulikan kondisi-kondisi tertentu yang ada dan lirih dalam kehidupan bersama. Namun lebih dari itu syariat Islam mengakui realitas kehidupan dan kondisi yang mungkin berubah dan silih berganti.

Sekarang kecenderungan aktifitas kerja ekonomi masyarakat terasa semakin kuat, tidak hanya kaum laki-laki, tetapi wanitapun mendapatkan peluang yang bagus untuk bekerja dengan baik dalam lapangan ekonomi maupun sosial. Mengenai rumah tangga dan partisipasi angkatan kerja wanita di Indonesia mengatakan bahwa Tenaga Kerja Wanita yang berfungsi sebagai kepala keluarga mempunyai tanggung jawab yang lebih besar, sehingga mempunyai tingkat partisipasi yang lebih tinggi dibanding tenaga kerja wanita yang tidak berfungsi sebagai kepala keluarga. Keikutsertaan wanita dalam kegiatan pasar dipengaruhi faktor pendidikan, permintaan terhadap Tenaga Kerja Wanita, meningkatnya produktifitas secara keseluruhan dan nilai (harga) upah pada pasar kerja tinggi. ${ }^{1}$

Bekerja diwajibkan bagi setiap individu yang mampu dengan berusaha mencari lapangan pekerjaan yang halal dan sesuai dengan norma-norma etika. Islam memberikan peluang bagi wanita untuk bekerja, sama dengan laki-laki. Komitmen Islam berada pada sejauh mana aktifitas pekerjaanya agar tidak menyalahi kodrat dan aturan-aturan agama Islam. Perekonomia sangat vital dalam kelangsungan rumah tangga. Untuk memenuhi kebutuhan rumah tangga, istripun rela bekerja, karena penghasilan suami yang tidak tetap dan tidak bisa mencukupi kebutuhan keluarga, istripun mencari pekerjaan, baik itu didalam lingkungan daerahnya sendiri maupun diluar daerah lingkungannya.

Atas asumsi di atas penulis memilih Desa Pambusuang Kec. Balanipa Kab. Polewali Mandar sebagai obyek penelitian, guna untuk mengetahui faktor apa saja yang melatar belakangi adanya seorang istri yang bekerja mencari nafkah dalam keluarga. Olehnya itu, adapun judul yang di angkat dalam penelitian adalah"Tinjauan Hukum Islam Terhadap Istri Sebagai Pencari Nafkah" (Study Kasus Masyarakat Di Desa. Pambusuang Kec. Balanipa Kab. Polewali Mandar). Sesuai dengan judul diatas adapun rumusan masalah yang akan diangkat oleh penulis dalam hal ini adalah: (1) bagaimana praktek istri yang mencari nafkah di Desa Pambusuang?, (2) bagaimana tinjauan Hukum Islam terhadap istri sebagai pencari nakah di Desa Pambusuang?.

\section{TINJAUAN PUSTAKA}

Hukum Islam adalah seperangkat peraturan berdasarkan peraturan wahyu Allah dan Sunnah Rasul tentang tingkah laku manusia mukallaf yang diakui dan diyakini mengikat untuk semua yang beragama Islam. Apabila akad nikah telah berlangsung dan sah memenuhi syarat dan rukunnya, maka akan menimbulkan akibat hukum. dengan demikian

${ }^{1}$ Rabihatun Rauf, Angkatan Kerja Wanita: Kasua Tiga Kota di Sulawesi Selatan, ( Cet. I; Makassar: Rayhan Intermedia, 2008), h. 19 
menimbulkan pula hak dan kewajibannya selaku suami istri dalam keluarga. ${ }^{2}$ Secara pengertian hak adalah kekuasaan atau wewenang yang dimiliki seorang untuk mendapatkan atau berbuat sesuatu. ${ }^{3}$

Sedangkan yang di maksud dengan hak ialah suatu yang merupakan milik atau dapat dimiliki oleh suami atau istri yang diperoleh dari hasil perkawinannya. Hak ini juga dapat hapus apabila yang berhak rela apabila haknya tidak dipenuhi atau dibayar oleh pihak lain. Adapun yang dimaksud dengan kewajiban ialah hal-hal yang wajib dilakukan atau diadakan oleh salah seorang dari suami-istri untuk memenuhi hak dari pihak lain. ${ }^{4}$

Hak dan kewajiban suami istri tercantum pada Kompilasi Hukum Islam (KHI): Suami istri memikul kewajiban yang luhur untuk menegakkan rumah tangga yang sakinah, mawadah, rahmah yang menjadi sendi dasar dari susunan masyarakat. a. Suami istri wajib saling mencintai, saling menghormati, setia dan memberi bantuan lahir batin yang satu kepada yang lain, b. Suami istri memikul kewajiban untuk mengasuh dan memelihara anakanak mereka, baik mengenai pertumbuhan jasmani, rohani, maupun kecerdasan dan pendidikan agamanya, c. Suami istri wajib menjaga kehormatannya, d. Jika suami atau istri melalaikan kewajibanya, masing-masing dapat mengajukan gugatan kepada pengadilan agama, e. Suami istri harus mempunyai tempat kediaman yang tetap. Dalam hal ini pembagian hak dan kewajiban disesuaikan dengan porsinya masing-masing. Bagi pihak yang di dikenakan kewajiban lebih besar berarti ia akan mendapatkan hak yang lebih besar pula. Sesuai dengan fungsi dan perannya. Dalam pasal 78 Kompilasi Hukum Islam berbunyi: 1 . Suami istri harus mempunyai tempat kediaman yang tetap, 2. Rumah kediaman yang dimaksud dalam ayat 1 ditentukan oleh suami istri. dan dalam pasal 79 mengungkapkan tentang kedudukan suami istri yang berbunyi: 1 . Suami adalah kepala keluarga dan istri ibu rumah tangga, 2. Hak dan kedudukan suami dalam kehidupan rumah tangga dan pergaulan hidup bersama dalam masyarakat, 3. Masing-masing pihak berhak untuk melakukan perbuatan hukum.

Pada undang-undang perkawinan tahun 1974 disebutkan tentang hak dan kewajiban suami istri dalam pasal 31 ayat 1 sangat jelas disebutkan bahwa kedudukan suami istri adalah sama dan seimbang, baik dalam kehidupan rumah tangga maupun dalam pergaulan hidup bermasyarakat.Pemberian nafkah menurut hokum islam. Nakah merupakan kewajiban suami, maksudnya adalah menyediakan segala keperluan dari istri. Adapun syarat-syarat dalam pemberian nafkah adalah akad pernikahan yang dilakukan adalah sah, istri menyerahkan dirinya pada suami, istri memungkinkan suaminuntuki menikmatinya, istri tidak menolak untuk berpindah ketempat manapun yang dikehendaki suami, dan keduanya memiliki kemampuan untuk menikmati hubungan suami istri. Nafkah wajib bagi istri selama ia menunaikan berbagai tanggungannya. Yaitu memenuhi batasan-batasan fitrahnya sebagai istri. Dan ketika seorang istri itu tidak bisa memenuhi kewajibanya sebagai istri, diantaranya istri sombong dengan fitrahnya, menyimpang dari aturan, berpaling pada jalan Allah,

\footnotetext{
${ }^{2}$ Abdul Rahman Ghazali, Fiqih Munakahat, (Cet. V: Jakarta, Kencana, 2012), h. 155

${ }^{3}$ J.C.T. Simorangkir, Rudi T. Erwin, J.T. Prasetyo, Kamus Hukum, (Jakarta: Sinar Grafika, 2005), h. 60

${ }^{4}$ Soemiyati, Hukum Perkawinan Islam dan Undang-undang Perkawinan, (Cet. II; Yogyakarta: Liberty, 1986), h. 87
} 
melampau suami dalam tujuan kehidupan rumah tangga maka istri tidak berhak mendapatkan hak ini. ${ }^{5}$

Adapun suami untuk mencukupi kebutuhan rumah tangga. Suami wajib memenuhi kebutuhan dapur, yakni memenuhi kebutuhan belanja pokok atau sembako, membiayai pendidikan anak, kesehatan dan sebagainya. Istri tidak wajib mencari nafkah kalaupun istri bekerja hal itu harus dilakukan atas izin suami dan sifatnya membantu perekonomian keluarga. Jika suami tidak menghendaki istri bekerja maka ia harus mentaatinya. ${ }^{6}$

Nafkah yaitu pemberian seseorang baik berupa makanan, pakaian, tempat tinggal ataupun ketentraman/kesenangan hidup (nafkah batin). Kepada seseorang disebabkan karena: perkawinan, kekeluargaan dan pemilikan/hak milik (hamba sahaya/budak), sesuai dengan kemampuan. Memberi nafkah kepada seseorang yang menjadi tanggung jawabnya, hukumnya wajib. Nafkah secara etimologi adalah apa yang kamu nafkahkan dankamu belanjakan untuk keluargamu dan untuk dirimu sendiri. Secara terminologi, memberi nafkah berarti mencukupi makanan, pakaian,dan tempat tinggal orang yang menjadi tanggungannya. ${ }^{7}$ Sedangkan menurut istilah ahli fiqh adalah pengeluaran yangharus dikeluarkan oleh orang yang wajib memberi nafkah kepada seseorang, baik berbentuk roti, gula, pakaian, tempat tinggal, dansegala sesuatu yang berhubungan dengan keperluan hidup seperti air,minyak, lampu, dan sebagainya. ${ }^{8}$ Nafkah adalah sesuatu yang diinfakkan atau dikeluarkan olehseseorang untuk keperluan keluarganya.Adapun nafkah menurut syara' adalah kecukupan yang diberikan seseorang dalam hal makanan, pakaian, dan tempat tinggal. ${ }^{9}$

Hukum membayar nafkah untuk istri, baik dalam bentuk perbelanjaan, pakaian adalah wajib. Kewajiban itu bukan disebabkan oleh karena istri membutuhkannya bagi kehidupan rumah tangga, tetapi kewajiban yang timbul dengan sendirinya tanpa melihat kepada keaadaan istri. ${ }^{10}$ Kewajiban suami memberi nafkah terkandung pula pada KHI pasal 80 ayat (4) yang berbunyi:

Sesuai dengan penghasilannya suami menanggung: a. Nafkah, kiswah dan tempat kediaman bagi isteri; $b$. Biaya rumah tangga, biaya perawatan dan biaya pengobatan bagi isteri dan anak; c. Biaya pendidikan bagi anak. ${ }^{11}$ Adapun sebab-sebab seseorang menerima nafkah yaitu,pertama nafkah sebab kerabat diwajibkan pada salah satu kepada yang lain karena asal

${ }^{5}$ Dr. Ali Yusuf As-Subki, Fiqih Keluarga Pedoman Berkeluarga Dalam Islam, (Jakarta: Amza, 2009), h.187

${ }^{6}$ Drs. Beni Ahmad Saebani, M.SI., Fiqih Munakahat 2, (Bandung: Pustaka Setia, 2001), h. 33

${ }^{7}$ Yahya Abdurrahman al-Khatib, Fiqih Wanita Hamil, (Cet, II; Jakarta: Qithi Press, 2005), h. 164

${ }^{8}$ Djamaan Nur, Fiqih Muakahat, (Semarang: Dina Utama Semarang, 1993), h. 100

${ }^{9}$ Az-Zuhaili, Fiqih Islam Wa Adillatuhu Jilid 10, (Jakarta: Gema Insani, 2011), h. 94

${ }^{10}$ Amir Syarifuddin, Hukum Perkawinan di Indonesia: Antara Fiqih Munakahat dan Undang-Undang Perkawinan, (Cet. II; Jakarta: Prenada Media, 2007) h. 166

${ }^{11}$ Amir Syarifuddin, Hukum Perkawinan di Indonesia: Antara Fiqih Munakahat dan Undang-Undang Perkawinan, (Cet. II; Jakarta: Prenada Media, 2007) h. 182 
dan kasih sayang. Orang tua menjadi asal adanya anak atau keturunan, maka orang tua wajib memberikan nafkah kepada anaknya dan anak wajib memberi nafkah kepada orang tuanya, baik terhadap laki-laki atau perempuan. Kedua nafkah sebah penikahan dan yang ketiga adalah nafkah sebab kepemilikan seperti halnya seseorang yang memiliki ternak harus diberi nafkah yang cukup misalnya harus digembalakan atau diberi makanan dan minuman.

\section{METODE PENELITIAN}

Lokasi penelitian yang dilakukan penulis adalah Desa Pambusuang Kec. Balanipa Kab. Polewali Mandar, waktu penelitian berjalan selam 2 bulan dari januari hingga akhir februari. Pada penelitian ini penulis menggunakan jenis penelitian Deskriptif Kualitatif maksudnya ialah prosedur penelitian yang menghasilkan data berupa kata-kata tertulis atau lisan dari orang-orang dan perilaku yang diamati. ${ }^{12}$ Sedangkan Deskriptif adalah melukiskan, memaparkan dan melaporkan suatu keadaan, objek, atau peristiwa secara apa adanya. ${ }^{13}$ Populasi adalah keseluruhan subyek penelitian. ${ }^{14}$ Adapun yang menjadi populasi dalam penelitian ini adalah Masyarakat Desa Pambusuang Kec. Balanipa Kab. Poewali Mandar. Sedangkan sample yang digunakan dalam penelitian ini adalah keseluruhan populasi dalam masyarakat Desa Pambusuang Kec. Balanipa Kab. Polewali Mandar. Adapun populasi yang dimaksud adalah para istri yang bekerja berjumlah 1000 orang, dan sampel yang digunakan adalah 5\% dari jumlah populasi yang ada sehingga dapat ditarik 50 orang sebagai responden yang digunakan sebagai obyek penelitian.

Pendekatan yaitu sifat suatu ilmu pengetahuan. Melaluinya, objek diungkapkan secara lebih objektif. Dalam kaitannya dengan hal ini, tampil pendekatan sosiologis, historis, psikologis, literre, antropologis, ekonomis, politis dan lain sebagainya. Sehingga berdasarkan penjelasan tersebut, maka terdapat beberapa pendekatan yang penulis gunakan dalam melakukan penyusunan kali ini yaitu sebagai berikut; 1. Pendekatan Sosial, yaitu dengan melakukan proses pemahaman dari seorang istri dan keadaan keluarga dalam masyarakat yang mendukung persoalan yang di bahas; 2. Pendekatan yuridis, yaitu melalui pendekatan Undang-Undang tentang objek kajian penelitian dalam hal ini ialah hukum kewajiban suami istri dalam pemenuhan nafkah; 3. Pendekatan syar'i, yaitu melalui pendekatan hukum Islam berdasarkan aturan-aturan nash Al-Qur'an dan hadist. Adapun metode pengumpulan data yang digunakan penulis ada dua yaitu Sumber data primer berupa, observasi partisipan, wawancara mendalam, serta dokumentasi. Dan yang kedua adalah sumber data sekunder yaitu sumber data yang secara tidak langsung memberi keterangan yang bersifat mendukung data primer. Adapun yang termasuk dalam sumber data sekunder adalah bahan-bahan dokumen, literatur-literatur, peraturan-peraturan, perundang-undangan dan arsip-arsip yang berhubungan dengan penelitian.

12 Andi Prastowo, Metode Penelitian Kualitatif Dalam Prespektif Rancangan Penelitian, (Cet. I; Jogjakarta: Ar-Ruzz Media, 2011), h. 22

${ }^{13}$ Agus Santoso, Sosiologi 3 Suatu Kajian Kehidupan Masyarakat, (Jakarta:

Yudhistira, 2007), h. 89

14 Suharsimi Arikunto, Prosedur Penelitian Suatu Pendekatan Praktek, (Jakarta:

Rineka Cipta, 1998), hlm. 115. 


\section{HASIL PENELITIAN}

A. Potret Istri yang Mencari Nafkah di Desa Pambusuang

Adapun potret yang dilakukan isteri dalam mencari nafkah di Desa Pambusuang adalah. a. Rosmini (47 tahun) dan Suaib (48 tahun); Rosmini selain sebagai seorang istri dan ibu dari lima (5) orang anak, ia juga bekerja sebagai seorang perias pengantin, selain untuk membantu suami dalam mencari nafkah Rosmini setiap pagi bergantian bersama suami mengantar anaknya ke sekolah. Pendidikan terakhirnya adalah Sekolah Menengah Atas (SMA). Suaminya Suaib, adalah seorang pendekor ruang pengantin, jadi Suaib dan Rosmini memiliki usaha bersama sebagai suami istri di rumah mereka. Saat bekerja Rosmini secara bergantian menjaga anak-anaknya. Jika Suaib melakukan pekerjaan maka di luar rumah maka, Rosmini yang akan mengurus segala hal yang ada di rumah begitu pula sebaliknya, jika ibu Rosmini yang keluar rumah untuk bekerja maka Suaib yang akan mengurus segala keperluan rumah. Bapak Suaib mengatakan,

"kenapa saya harus melarang istri untuk bekerja, padahal hal itu sangat membantu dalam memenuhi kebutuhan keluarga kami, banyak hal yang harus kami pikirkan selain untuk mencukupi kebutuhan sehari-hari, saya dan istri jaga harus menabung untuk biaya sekolah anak-anak kami". ${ }^{15}$

Begitu pula sebaliknya ibu Rosmini mengungkapkan,

"sangat banyak biaya yang keperluan anak-anak yang harus kami beli, terutama untuk anak terakhir kami yang baru berusia satu tahun. Untuk beli susu, popoknya dan keperluan lainnya. Jika hanya mengandalkan pemasukan dari suami, yang tidak jelas kapan akan ada lagi orang yang akan menyewa jasa kami, itu tidaklah akan mencukupinya. Jadi saya meminta suami agar dapat mengikuti kursus merias dan pada akhirnya saya turut menbantu suami dalam mencari nafkah". ${ }^{16}$

Lujuna (43 tahun) dan Alimuddin (47 tahun); Ibu Lujuna adalah seorang penjual ikan, ia menjual ikannya bukan hanya di pasar tapi terkadang menjualnya dengan berkeliling desa menggunakan sepeda motor. Setiap hari pasar di Desa Pambusuang yaitu senin dan jum'at, setiap pagi sehabis shalat subhu ikan lansung berangkat ke pasar dan akan pulang jika ikannya telah habis terjual atau jiaka waktu bubar pasar telah usai. Pendidikan ibu Lujuna adalah SMA, dan memiliki dua orang anak. Suaminya, Alimuddin adalah seorang nelayan yang ikut pada kapal besar. Pendidikan terakhirnya adalah SMP, penghasilannya tidaklah tetap, bahkan terkadang tak mendapatkan hasil. Pekerjaannya sebagai nelayan yang ikut pada kapal besar membuatnya selalu pergi 3-6 bulan. Penghasilnnya yang tidak menentu membuatnya merasa bersyukur bahwa istrinya juga bekerja. Ia mengatakan,

"iyau posasi a, simata meccoea lao kappalna punggawau. Simata lamba a' masae, biasa tallum bulang bahkan sampai annan bulan. Iyapa' namala tau makkirim do'i lao baine ta mua diang bo'o tomalai. Macoa sannal tiya rie'e apa mambalu toi tiya

15 Suaib, Desa Pambusuang Kec. Balanipa Kab. Polewali Mandar, wawancara oleh penulis, 25 Maret 2017

${ }^{16}$ Rosmini, Desa Pambusuang Kec. Balanipa Kab. Polewali Mandar, wawancara oleh penulis, 25 Maret 2107 
amma' na'.,"17 "Saya seorang nelayan, selalu ikut dengan pemilik kapal. Terkadang perginya sangat lama, bisa 3 bulan bahkan sampai 6 bulan. Akan bisa mengirim uang ketika ada orang yang akan pulang ke kampung. Hal ini sangat bagus karena istriku juga pergi menjual ikan."

Suratima (44 tahun) dan Junaidi (49 tahun); Ibu Suratima bekerja sebagai penenun, ia memiliki tujuh orang anak. Pendidikan terakhirnya adalah MTs atau setara dengan SMP, karena menikah diusia muda anak-ankanya telah beranjak dewasa bahkan ia telah memiliki cucu. Ibu suratima biasanya menenun di rumah, penghasilan yang ia perolehpun tidak cukup untuk kebutuhan sehari-hari. Ia terpaksa harus bekerja agar paling tidak dapat sedikit menutupi biaya hidup sehari-hari. Suaminya, Junaidi adalah seorang nelayan. Karena ia adalah nelayan yang mencari penghasilan di luar kota maka, terkadang ia pergi 3-6 sama halnya dengan suami ibu Lujuna. Pendidikan terakhinya adalah SMP. d. Reski (41 tahun) dan Syarifuddin (52 tahun); Ibu Reski adalah seorang penenun sarung, memiliki 3 orang anak. Pendidikan terakhirnya SMA, jika bertenun setiap hari ia dapat menyelesaikan satu sarung dalam lima hari, dan mendapat hasil dua ratus ribu rupiah bahkan sampai 500 ribu rupiah. Selain bertenun ia juga biasanya menjual sayur yang ia tanam sendiri bersama dengan saudaranya. Suaminya, Nasaruddin adalah seorang nelayan yang penghasilannya tidaklah tetap apalagi untuk menyekolahkan anak-anaknya. Maka dari itu, ibu Reski turut serta dalam mencari nafkah agar dapat menbantu suaminya dan sedikit mengurangi beban ekonomi keluarganya.

Ibu Reski mengungkapkan;

"jika hanya mengandalkan pengasilan dari suami tidak akan cukup untuk memenuhi kebutuhan sehari-hari, apalagi jika profesi suami adalah seorang nelayan yang menangkap ikan sampai keluar kota tentu hal itu, sampai berbulanbulan. Dimana, saya sebagai istri dan anak-anaknya ditinggalkan lalu apa yang harus kami andalakan jika hanya menunggu kiriman dari suami. Makanya saya pergi ke pasar menjual ikan dan terkadang bekeliling desa menggunakan sepeda motor menjual ikannya. Namun perlu diketahui bahwa ibu-ibu yang menjual ikan, sebenarnya tidaklah menjual ikannya sendiri melainkan ikan orang lain yang mereka beli lalu dijual kembali. Jika tidak seperti itu maka untuk makan sehari-hari sekalipun tidak akan bisa". ${ }^{18}$

Nurul (23 tahun) dan Arid (38 tahun); Nurul adalah seorang ibu rumah tangga sekaligus seorang pengusaha rumahan. Pendidikan terakhirnya adalah Madrasah Aliyah (MA) atau setara dengan SMA. Nurul memiliki usaha hand made,${ }^{19}$ dan toko campuran yang ada di ruamh. Suaminya, Arid adalah seorang guru ngaji . Pendidikan terakhirnya S1, walaupun pendidikannya tinggi tidak tahu karena alasan apa ia memilih untuk tetap hanya mengajar anak-anak mengaji. Awalnya bapak Arid bekerja sebagai guru honorer, akan tetapi

${ }^{17}$ Alimuddin, Desa Pambusuang Kec. Balanipa Kab. Polewali Mandar, wawancara oleh penulis, 28 Maret 2017

${ }^{18}$ Reski, Desa Pambusuang Kec. Balanipa Kab. Polewali Mandar, wawancara oleh penulis, 28 Maret 2017

${ }^{19}$ Hand made yaitu kerajinan yang dibuat dengan tangan sendiri. 
penghasilan sebagai guru honerer tidak cukup pula untuk menanggung keburuhan ekonomi keluarga, namun telah 2 tahun ia berhenti dan hanya fokus pada mengar anak-anak mengaji. Nurul sadar bahwa suaminya tidak terlalu memikirkan ataupun mengejar materil, jadi ia meminta izin pada suaminya untuk membuka toko campuran di rumah orang tuanya dan membuka usaha hand made. Usaha hand made yang ia jalankan adalah mebuat bros jilbab, menerima pesanan dari ibu-ibu pengajian atau menjualnya ke pedangang pasar. Dari penghasilannya tersebut paling tidak dapat menutupi kebutuhan keluarga setiap harinya.

Bapak Arid mengungkapkan;

"saya dan istri bekerjasama untuk memenuhi kebutuhan keluarga, walaupun hanya mengajar anak-anak mengaji istriku tak pernah mengeluh berapapun penghasilan yang saya berikan padanya. Walaupun istri juga mencari nafkah tetapi saya sebagai laki-laki dan kepala rumah tangga akan meras malu jika kami tak memberikan nafkah kepada keluarga, tapi saya juga merasa bersyukur bahwa istri saya membantu dalam memenuhi kebutuhan keluarga kami, dan kami saling menghormati atas apapun yang ada dalam rumah tangga ini" ${ }^{20}$

Mella (43 tahun) dan Haliq (47 tahun); Ibu Mella memiliki usaha warung yang ada di rumahnya, setiap hari ia buka dari pukul 07:00 - 17:30. Rutinitas yang ia lakukan setiap hari adalah berada di warungnya, pekerjaannya tersebut telah ia lakukan selama dua tahun terakhir. Selain menjual makanan buatannya sendiri, ia juga menerima kue-kue yang dititipkan oleh tetangganya. Suaminya, Haliq adalah seorang buruh bangunan. Bekerja sebagai buruh bangunan penghasilannya tidaklah tetap maka dari itu ia mengizinkan istrinya ikut serta dalam mencari penghasila, bukan sekedar hanya karena membantunya akan tetapi ibu Mella melakukan pekerjaan tidaklah keluar dari rumah.

\section{B. Tinjaun Hukum Islam Terhadap Istri Sebagai Pencari Nafkah Di Desa Pambusuang}

Untuk mengetahui bagaimana tinajauan hukum Islam terhadap istri sebagai pencari nafkah, selain melihat lansung potret dari keluarga di Desa Pambusuang yang dijadikan sebagai objek penelitian, penulis juga mengkaji dan melakukan wawancara pada beberapa ulama yang ada di desa Pambusuang untuk lebih mengetahui bagaimana hukum yang berkembang pada masyarakat yang ada di desa Pambusuang.

Beberapa hasil wawancara yang dilakukan penulis, sebagai berikut:

Diungkapkan oleh K.H. Bisri, yang merupakan imam masjid At-Taqwa Pambusuang, beliau menyatakan

"yang seharusnya bekerja untuk memenuhi kebutuhan ekonomi rumah tangga adalah bapak atau suami, karena itu merupakan tanggung jawab dari seorang kepala rumah tangga. Seorang yang menyatakan sudah siap berumah tangga maka ia pun akan sudah siap untuk menafkahi keluarganya dan tentunya ia mempunyai penghasilan yang cukup untuk memberi makan kelurga walaupun ia hanya seorang petani, atau seorang buruh sekalipun. Dan istri tentunya harus dapat mengatur

${ }^{20}$ Arid, Desa Pambusuang Kec. Balanipa Kab. Polewali Mandar, wawancara oleh penulis, 01 April 2017 
dengan baik mengenai keunagan ruamah tangga, sehinnga mencukupi untuk kebutuhan sehari-hari. Jika seorang istri tidak dapat mengatur keuangan rumah tangganya, maka berapapun pengahasilan dari suami baik itu besar atau kecil tentu tidak akan pernah mencukupi untuk memenuhi kebutuhan rumah tangga. Hal ini terjadi hanya disebagian kecil masyarakat desa pambusuang ini. Rata-rata kepala kelurga di desa pambusuang ini melibatkan istrinya untuk bekerja membantu mereka (suami), bahkan tidak jarang penghasilan si istri itu melebihi dari penghasilan suami. Tentunya ini bertolak belakang dengan tanggu jawab dari seorang suami', 21

Namun K.H. Bisri juga mengungkapkan bahwa

"dalam hal istri yang ikut serta dalam mencari nafkah bukan sebuah persoalan besar selama suami mengizinkan dan tidak adanya terjadi hal-hal yag tidak seharusnya. Intinya adalah jika istri ingin bekerja maka ia harus mendapat izin dari suami terlebih dahulu".

Sama halnya dengan yang diungkapkan oleh ustads Syahid bahwa

"tidaklah wajib seorang isteri mencari nafkah karena itu adalah tuga dari suami namun boleh menjadi kelebihan pahala dan kebaikan ketika seorang isteri mencari nafkah, dan tetap tidak merubah tugas utamanya dalam rumah tangga. Bahkan seorang isteri ketika ingin keluar rumah harus izin dari suami. Akan menjadi haram ketika isteri bekerja namun menelantarkan keluarganya".

Ustadas syahid juga mengungkapkan

"tidak ada masalah ketika perempuan ingin bekerja seperti pekerjaan laki-laki selama ia mampu dan kuat untuk melakukannya. Karena sebenarnya pengelompokkan pekerja kasar dan ringan relatif tidak ada ukurannya, sepanjang ia mampu melakukannya baik perempuan maupun laki-laki". ${ }^{22}$

Sama halnya dengan wawancara yang dilakukan penulis pada Ustads Ilham Sopu selaku kepala sekolah Madrasah Aliyah Pambusuang bahwa

"dalam islam tidak ada yang menyatakan bahwa isteri dilarang bekerja karena seperti halnya dalam pengungkapan sejarah bahkan isteri Rasulullah saja adalah seorang pedagang. Jadi tidak ada larangan yang tidak membolehkan seorang isteri untuk bekerja apalagi jika isteri bekerja malah membantu untuk mencukupi kebutuhan keluarga yang tidak dapat tercukupi hanya dari penghasilan suami. Jika suami memberi izin pada istri maka isteripun harus dapat memamfaatkan hal tersebut dengan baik dengan tidak melanggar kepercayaan dari suami maka hal yang tidak dinginkan akan tetap terhindari. Suami isteri bekerjasama dalam memenuhi ekonomi keluarga adalah hal yang baik. Akan tumbuh rasa saling menghormati dikarenakan isteri mengerti akan susahnya mencari nafkah begitupula suami yang mengerti dalam akan perasaan isteri. Maka akan memupuk

\footnotetext{
${ }^{21}$ Bisri, Desa Pambusuang Kec. Balanipa Kab. Polewali Mandar, wawancara oleh Penulis, 04 April 2017

${ }^{22}$ Syahid, Desa Pambusuang Kec. Balanipa. Kab. Polewali Mandar, wanwancara oleh penulis, 05 April 2017
} 
rasa saling mencintai dan menghormati dalam rumah tangga mereka. Jika ditanyakan apakah boleh isteri bekerja mencari nafkah, maka jawabannya adalah boleh selama isteri meminta izin dan suami memberi izin". ${ }^{23}$

Dari observasi dan wawancara yang dilakukan oleh penulis terhadap beberapa responden diketahui bahwa, ternyata bukan hanya istri saja yang ikut serta dalam memenuhi kebutuhan rumah tangga, bahkan banyak dari anak-anak dalam keluarga tersebut yang juga bekerja walaupun hanya sekedar untuk mendapakan uang jajan. Seperti, jika ibunya seorang pembuat kue maka anaknya akan berkeliling desa untuk menjajakan kue tersebut, dan begitu pula jika seorang nelayan pinggiran pada pagi hari atau sore hari maka anak-anak akan menjualkan dengan berkeliling desa.

\section{PENUTUP}

Berdasarkan dari analisis dan perumusan masalah di atas, maka penulis menyimpulkan:

A. Antara suami dan isteri di desa Pambusuang mereka saling bekerja sama dalam memenuhi kebutuhan ekonomi, diantaranya: Jika suaminya seorang nelayan maka para isteri membantu dalam menjual ikan, adapula suami yang seorang interior pernikahan, istrinya seorang perias pengantin. Suaminya seorang guru ngaji, istrinya membuka sebuah toko campuran di rumah, dan suami yang bekerja sebagai nelayan, istrinya bertenun.

B. Bahwa isteri yang ikut serta dalam mencari nafkah untuk memenuhi kebutuhan keluarga adalah mubah (boleh). Alasannya adalah boleh karena para isteri tidak melalaikan tanggung jawab utama dalam rumah tangga, boleh karena para suami memiliki kerelaan dan merasa bersyukur atas ikut serta isterinya yang membantu mencukupi kebutuhan ekonomi, boleh karena pekerjaan yang dilakukan para isteri tidak menyalahi aturan agama. Sedangkan saran yang dapa diberikan oleh penulis adalah diharapkan kepada pemerintah daerah agar dapat memperhatikan potensi yang ada di Desa-desa dan memfasilitasi kerajinan ekonomi keluarga yang dapat diberikan modal sehingga para wanita yang bekerja baik sebagai penjual ikan maupun yang lainnya lebih mampu berkembang sebuah industri kecil-kecilan.

\section{Datar Pustaka}

Abdurrahman, Yahya al-Khatib, Fiqih Wanita Hamil, (Cet, II; Jakarta: Qithi Press, 2005)

Ahmad, Beni Saebani, M.SI., Fiqih Munakahat 2, (Bandung: Pustaka Setia, 2001)

Arikunto, Suharsimi, Prosedur Penelitian Suatu Pendekatan Praktek, (Jakarta: Rineka Cipta, 1998)

Az-Zuhaili, Fiqih Islam Wa Adillatuhu Jilid 10, (Jakarta: Gema Insani, 2011)

Nur, Djamaan, Fiqih Muakahat, (Semarang: Dina Utama Semarang, 1993)

${ }^{23}$ Ilham Sopu, Desa Pambusuang Kec. Balanipa Kab. Polewali Mandar, wawancara Oleh Penulis, 06 April 2017 
Vol. 2, No. 1, Mei 2017

p-ISSN: 2541-5212 | e-ISSN: 2541-5220

J-ALIF Jurnal Penelitian Hukum Ekonomi Syariah dan Sosial

Budaya Islam

Prastowo, Andi, Metode Penelitian Kualitatif Dalam Prespektif Rancangan Penelitian, (Cet. I; Jogjakarta: Ar-Ruzz Media, 2011)

Rahman, Abdul Ghazali, Fiqih Munakahat, (Cet. V: Jakarta, Kencana, 2012)

Rauf, Rabihatun, Angkatan Kerja Wanita: Kasua Tiga Kota di Sulawesi Selatan, ( Cet. I; Makassar: Rayhan Intermedia, 2008)

Syarifuddin, Amir, Hukum Perkawinan di Indonesia: Antara Fiqih Munakahat dan UndangUndang Perkawinan, (Cet. II; Jakarta: Prenada Media, 2007)

Santoso, Agus, Sosiologi 3 Suatu Kajian Kehidupan Masyarakat, (Jakarta: Yudhistira, 2007) 